\title{
KEGIATAN USAHA PT. PELABUHAN INDONESIA PASCA LAHIRNYA UNDANG-UNDANG NOMOR 17 TAHUN 2008 TENTANG PELAYARAN DALAM PERSPEKTIF HUKUM PERSAINGAN USAHA
}

\section{Muhammad Annas}

Fakultas Hukum Universitas Muhammadiyah Yogyakarta

Jl. Ring Road Barat, Tamantirto, Kasihan, Tamantirto, Kasihan, Bantul, Daerah Istimewa

Yogyakarta 55184, Telp/Fax: (0274) 387656, e-mail: mannas@umy.ac.id

\begin{abstract}
Abstrak
Lahirnya Undang-Undang Nomor 17 Tahun 2008 tentang Pelayaran telah memisahkan fungsi regulator dan operator dalam industri pelabuhan. Lahirnya Undang-Undang tersebut menyebabkan PT. Pelabuhan Indonesia hanya berwenang sebagai operator dan berubah status menjadi pelaku usaha biasa. Oleh karena itu Undang-Undang Pelayaran yang baru menjadikan hak monopoli PT. Pelabuhan Indonesia pada kegiatan usaha industri pelabuhan dihapuskan. Masalah muncul ketika perubahan Undang-Undang Pelayaran tidak diikuti dengan perubahan perilaku PT. Pelabuhan Indonesia yang masih seakan-akan memiliki hak monopoli dengan menjadikan dasar Surat Menteri Perhubungan Nomor HK 003/1/11Phb2011 tanggal 6 Mei 2011. Hasil penelitian ini menunjukan bahwa dasar yang digunakan oleh PT. Pelabuhan Indonesia tidaklah tepat dan bertentangan dengan UndangUndang Nomor 5 Tahun 1999. Selain itu monopoli PT. Pelabuhan Indonesia tidak termasuk monopoli yang dikecualikan dalam Undang-Undang Nomor 5 Tahun 1999.
\end{abstract}

Kata Kunci: Hukum Persaingan Usaha, Monopoli, PT. Pelabuhan Indonesia

\section{A.Pendahuluan}

Pemenuhan akan kebutuhan seharihari masyarakat sangat penting. Hal tersebut juga menjadi salah satu tanggung jawab penting yang harus dijamin oleh negara. Indonesia termasuk sebagai salah satu negara dengan jumlah penduduk terbanyak di dunia tentunya harus memberikan perhatian khusus untuk hal tersebut. Selain itu Undang-Undang Dasar Negara Republik Indonesia tahun 1945 juga diatur mengenai tujuan negara yang kebutuhan masyarakat Indonesia tidak dapat terpenuhi dengan baik maka akan sulit untuk mewujudkan kesejahteraan bagi rakyat.

Pelabuhan adalah sektor vital dalam kehidupan sosial dan perekonomian Indonesia. Hal tersebut diperkuat dengan alasan keagadaan geografis Indonesia. Secara geografis Indonesia adalah negara kepulauan yang tentunya sangat 
membutuhkan pelabuhan sebagai sarana pendukung kegiatan ekonomi masyarakat.

Aktivitas kerja di pelabuhan sangat kompleks. Pelabuhan laut merupakan pintu keluar masuknya berbagai arus. Arus barang, arus jasa, arus kapal, arus penumpang, arus anak buah kapal, arus devisa, arus hewan, arus tumbuhan, arus virus dan bakteri, arus kutu dan serangga, arus dokumen, arus transportasi darat, arus logistic kapal termasuk BBM dan air bersih, dan lainnya semuanya bisa melalui pelabuhan. ${ }^{1}$

Pelabuhan sebagai sarana yang mendukung perdagangan serta pendistribusian barang yang dibutuhkan oleh masyarakat. Pelabuhan menjadi unsur penentu terhadap aktivitas perdagangan. Oleh karena itu pengelolaan pelabuhan secara efisien juga akan berpengaruh pada kemajuan perdagangan dan industri yang ada di daerah terbelakang pun juga akan ikut maju. $^{2}$

Dari aspek sosial pelabuhan menjadi fasilitas umum bagi masyarakat dalam melangsungkan interaksi termasuk di dalamnya aktivitas ekonomi. Selain itu pelabuhan merupakan sarana yang mendukung proses pengangkutan dan

1 Herman Budi Sasono, (2012), Manajemen Pelabuhan \& Realisasi Ekspor Impor, Yogyakarta: Penerbit ANDI, hlm. 13

2 D.A. Lasse, (2014), Manajemen Kepelabuhanan, Jakarta: Rajawali Pers, hlm.5. pergerkan manusia dari tempat suatu tempat ke tempat yang lain. ${ }^{3}$

Sebagai sektor vital, menjadi sebuah keharusan bagi negara untuk melakukan penguasaan terhadap sektor pelabuhan. ${ }^{4}$ Penguasaan negara terhadap sektor pelabuhan sangatlah penting. Selain karena pelabuhan merupakan sektor vital, pelabuhan juga merupakan sektor yang berkaitan dengan hajat hidup orang banyak. ${ }^{5}$ Penguasaan sektor yang berkaitan dengan hajat hidup orang banyak tersebut sesuai dengan amanah Pasal 33 ayat (2) Undang-Undang Dasar Negara Republik Indonesia Tahun 1945. ${ }^{6}$ Pasal 33 ayat (2) Undang-Undang Dasar 1945 telah menujukkan bahwa Negara Indonesia secara eksplisit telah mengamanatkan untuk menjaga kekayaan alam Indonesia

3 Hamud Balfas, (2015), Kajian Privatisasi Pelabuhan Berdasarkan Undang-Undang Nomor 17 Tahun 2008 tentang Pelayaran, Jurnal Hukum PRIORIS, Vol. 4 No.3, hlm. 244

${ }^{4}$ Presiden RI.go, Menyederhanakan Perizinan Pelabuhan, Tersedia pada http://www.presidenri.go .id/maritim/menyederhanakan-perizinan-

pelabuhan.html, [akses pada tanggal 2 Agustus 2017].

5 Gatra.com, Pelindo II: Monopoli Sah Menurut Undang-

Undang, Tersedia pada http://www.gatra.com/eko nomi-1/28991-pelindo-ii-monopoli-sah-menurutundang-undang.html, [Akses pada tanggal 2 Agustus 2017].

6 Lihat Pasal 33 ayat (2) Undang-Undang Dasar Negara Republik Indonesia Tahun 1945. 
dan mengelolanya untuk kemakmuran bangsa. $^{7}$

Berdasarkan hal-hal yang telah diuraikan sebelumnya penguasaan negara terhadap sektor pelabuhan sangat penting. Guna mewujudkan penguasaan negara terhadap sektor pelabuhan, pemerintah Indonesia membuat suatu peraturan yang dapat mengakomodir kebutuhan tersebut. Melalui Undang-Undang Nomor 21 Tahun 1992 tentang Pelayaran, pemerintah Indonesia memberikan kepercayaan kepada PT. Pelabuhan Indonesia untuk melakukan penguasaan sektor pelabuhan. Inilah bentuk dari penguasaan negara terhadap pelabuhan yang merupakan sektor penting bagi negara Indonesia yang berkaitan dengan hajat hidup orang banyak. $^{8}$

PT. Pelabuhan Indonesia merupakan Badan Usaha Milik Negara yang bergerak dalam sektor pelabuhan. Sebagai Badan Usaha Milik Negara PT. Pelabuhan Indonesia dapat melakukan monopoli asalkan ada penunjukan yang dilakukan oleh negara. Penunjukan PT. Pelabuhan Indonesia untuk melakukan

\footnotetext{
7 Fahri Hamzah, (2012), Negara BUMN dan Kesejahteraan Rakyat, Jakarta: Yayasan Faham Indonesia, hlm. 33.

8 Barada Giyantana, (2013), Implementasi Kebijakan Restrukturisasi Pengelolaan Pelabuhan (Studi Kasus di PT. (Persero) Pelabuhan Indonesia III Cabang Tanjung Perak Surabaya, Journal Universitas Airlangga Kebijakan dan Manajemen Publik, Volume 1, Nomor 1, Surabaya, hlm.63
}

monopoli pada sektor pelabuhan melalui Undang-Undang Nomor 21 Tahun 1992 sesuai dengan Pasal 50 huruf a dan Pasal 51 Undang-Undang Nomor 5 Tahun 1999 tentang Larangan Praktek Monopoli dan Persaingan Usaha Tidak Sehat.

Dalam Pasal tersebut dikatakan bahwa perbuatan dan atau perjanjian yang bertujuan untuk melaksanakan UndangUndang yang berlaku dikecualikan untuk tetap dapat dilakukan. Selain itu Pasal 51 Undang-Undang Nomor 5 Tahun 1999 tentang Larangan Praktek Monopoli dan Persaingan Usaha Tidak Sehat juga memberikan pengecualian yang membolehkan monopoli dilakukan oleh BUMN, badan, atau lembaga yang ditunjuk oleh negara selama monopoli tersebut diperuntukan bagi sektor yang berkaitan dengan hajat hidup orang banyak dan cabang produksi yang penting oleh negara.

Walaupun demikian, pemberian wewenang oleh pemerintah kepada PT. Pelabuhan Indonesia untuk melakukan monopoli tidak efisien. Hal ini terbukti dengan adanya putusan Komisi Pengawas Persaingan Usaha yang memperlihatkan adanya praktik monopoli yang dilakukan oleh PT. Pelabuhan Indonesia yang menyebabkan terjadinya persaingan usaha yang tidak sehat. Akibat dari praktek 
monopoli yang dilakukan oleh PT. Pelabuhan Indonesia, PT. Pelabuhan Indonesia dilaporkan oleh pelaku usaha lain yang bergerak dalam sektor pelabuhan atas dugaan pelanggaran terhadap UndangUndang Nomor 5 Tahun 1999 tentang Larangan Praktek Monopoli dan Persaingan Usaha Tidak Sehat.

Untuk mengakhiri permasalahan pada pengelolaan pelabuhan yang tidak efisien, pemerintah menciptakan peraturan yang baru yaitu Undang-Undang Nomor 17 Tahun 2008 tentang Pelayaran. Lahirnya Undang-Undang Nomor 17 Tahun 2008 tentang Pelayaran menyebabkan PT. Pelabuhan Indonesia kehilangan hak monopolinya pada sektor pelabuhan yang sebelumnya diatur dalam Undang-Undang yang lama yaitu UndangUndang Nomor 21 Tahun 1992.

Masalah muncul ketika lahirnya Undang-Undang Nomor 17 Tahun 2008 tidak diikuti dengan perubahan perilaku PT. Pelabuhan Indonesia dalam melakukan kegiatan usahanya pada sektor pelabuhan. Hal tersebut dapat kita lihat melalui beberapa putusan Komisi Pengawas Persaingan Usaha terhadap PT. Pelabuhan Indonesia baik sebelum maupun setelah lahirnya Undang-Undang Nomor 17 Tahun 2008 tentang Pelayaran. Setidaknya ada 4 putusan Komisi Pengawas Persaingan
Usaha yang membuktikan bahwa PT. Pelabuhan Indonesia telah melakukan pelanggaran terhadap Undang-Undang Nomor 5 Tahun 1999 tentang Larangan Praktek Monopoli dan Persaingan Usaha Tidak sehat.

Masalah lain adalah terjadi perbedaan pendapat antara Komisi Pengawas Persaingan Usaha dengan PT. Pelabuhan Indonesia terkait dugaan praktek monopoli yang dilakukan oleh PT. Pelabuhan Indonesia. Menurut Komisi Pengawas Persaingan Usaha PT. Pelabuhan Indonesia tidak lagi memiliki hak monopoli sejak lahirnya UndangUndang Nomor 17 Tahun 2008 tentang Pelayaran. Disisi lain pihak PT. Pelabuhan Indonesia menganggap masih memiliki kewenangan untuk melakukan monopoli didasarkan pada , Kepmen Menteri Perhubungan No. KP 98 Tahun 2011 tentang Pemberian Izin Usaha kepada PT Pelindo II sebagai Badan Usaha Pelabuhan, dan Surat Menteri Perhubungan Nomor HK 003/1/11Phb2011 tanggal 6 Mei 2011 perihal pelaksanaan ketentuan undangundang Nomor 17 Tahun 2008 tentang Pelayaran terhadap PT Pelabuhan Indonesia I, II, III, dan IV (Persero).

Rumusan Masalah 
Berdasarkan uraian yang telah diuraikan pada pendahuluan tulisan ini, penulis mengangkat sebuah rumusan masalah yaitu:

1. Bagaimana status monopoli yang dilakukan oleh PT. Pelabuhan Indonesia (PT.PELINDO) ditinjau dari persepektif hukum persaingan usaha?

\section{B. Metode Penelitian}

Adapun metode penelitian yang digunakan oleh penulis dalam menulis tulisan ini adalah dengan menggunakan pendekatan yuridis normatif. Penulis mencoba melakukan kajian pustaka terkait dengan isu yang penulis angkat dalam tulisan ini. Selain itu isu yang penulis angkat juga dikaji dengan melakukan tinjauan terhadap norma-norma hukum yang terdapat dalam peraturan perundangundangan yang terkait dengan industri pelabuhan dan kaitannya dengan perspektif hukum persaingan usaha.

\section{Pembahasan}

Pencabutan Monopoli PT. Pelabuhan Indonesia Melalui Undang-Undang Nomor 17 Tahun 2008 tentang Pelayaran

$$
\text { Lahirnya Undang-Undang Nomor }
$$

17 Tahun 2008 tentang Pelayaran menggantikan Undang-Undang sebelumnya yaitu Undang-Undang Nomor
21 Tahun 1992 membawa perubahan yang signifikan pada pengelolaan pelabuhan. PT. Pelabuhan Indonesia yang merupakan BUMN sekaligus Badan Usaha Pelabuhan tidak dapat melakukan monopoli pada pengelolaan pelabuhan. Adapun PT. Pelabuhan Indonesia sebagai Badan Usaha Pelabuhan adalah badan usaha yang khusus melakukan bidang pengusahaan terminal dan fasilitas lainnya. ${ }^{9}$

Undang-Undang Nomor 17 Tahun 2008 tentang Pelayaran mengatur mengenai pemisahan fungsi regulator dan operator dalam industri pelabuhan. ${ }^{10}$ Secara umum perubahan tersebut mengenai pemisahan organisasi yang ada di Pelabuhan. Pemisahan yang dimaksud antara lain: ${ }^{11}$

1. Syahbandar akan menjalankan fungsi keamanan dan keselamatan pada sektor pelayaran. Hal-hal tersebut mencakup pelaksanaan pengawasan dan penegakan hukum di bidang angkutan perairan, kepelabuhan dan perlindungan lingkungan maritim di pelabuhan. Adapun tugas-tugas dari syahbandar

9 Lihat Pasal 1 angka 11 Peraturan Menteri Perhubungan Republik Indonesia Nomor 23 Tahun 2015 tentang Peningkatan Fungsi Penyeleggara pada Pelabuhan yang Diusahakan Secara Komersial.

${ }^{10}$ Lihat penjelasan umum poin $\mathrm{b}$ Undang-Undang Nomor 17 Tahun 2008.

${ }^{11}$ Majalah KPS Kemitraan Prasarana \& Sarana (ed 3), (2008),http://pkps.bappenas.go.id/dokumen/maj alah/KPS\%20edisi\%20Nov08.pdf, [Akses 5 Januari 2017] 
akan lebih difokuskan pada pengawasan, mulai dari kelayakan kapal, lalulintas di perairan pelabuhan hingga memimpin gugus tugas penanggulangan pencemaran di pelabuhan.

2. Adanya pemisahan yang jelas antara otoritas pelabuhan untuk pelabuhan komersil dan unit penyelenggara pelabuhan (UPP) untuk pelabuhan non komersil. Nantinya otoritas pelabuhan akan diselenggarakan melalui badan terendiri oleh pemerintah. Adapun fungsi badan tersebut akan meliputi pembinaan, pengendalian dan pengawasan kegiatan pada pelabuhan yang diusahakan secara komersil. Ada sederet tugas penting dari otoritas pelabuhan, yakni mengatur dan mengawasi penggunaan lahan daratan dan perairan pelabuhan, mengawasi penggunaan daerah lingkungan kerja pelabuhan dan daerah lingkungan kepentingan pelabuhan, mengatur lalulintas kapal di pelabuhan serta menetapkan standar kinerja operasional pelayanan jasa kepelabuhan.

3. Pasal 91 Undang-Undang Nomor 17 Tahun 2008 juga mengatur mengenai pengusahaan pelabuhan. Dalam hal ini akan dibedakan antara pelabuhan komersial dan pelabuhan non komersial. Untuk penyelenggara usaha pelabuhan komersial dilakukan oleh badan usaha pelabuhan sendangkan untuk pelabuhan non komersial akan dilakukan oleh UPP. Khusus mengenai badan usaha, fungsi yang harus dijalankan adalah kegiatan jasa pengusahaan yang terdiri atas penyediaan dan/atau pelayanan jasa kepelabuhan dan jasa ini meliputi jasa dermaga untuk bertambat, pengisian bahan bakar dan air bersih, fasilitas naik turun penumpang dan barang, kegiatan bongkar muat barang dan peti kemas, jasa gudang, terminal dan penundaan kapal. Dalam keadaan tertentu, terminal dan fasilitas pelabuhan lainnya pada pelabuhan yang diusahakan UPP dapat dilaksanakan oleh badan usaha pelabuhan berdasarkan perjanjian.

Terkait dengan status PT. Pelabuhan Indonesia, lahirnya Undang-Undang Nomor 17 Tahun 2008 tentang Pelayaran mengubah PT. Pelabuhan Indonesia yang sebelumnya menjalankan fungsi regulator sekaligus sebagai operator. Sejak lahirnya Undang-Undang Nomor 17 Tahun 2008 tentang Pelayaran fungsi regulator sepenuhnya dipegang oleh pemerintah yang dalam hal ini adalah Kementerian Perhubungan yang kemudian dilakukan oleh Otoritas Pelabuhan. Adapun fungsi 
operator diberikan kepada BUMN yaitu PT. Pelabuhan Indonesia atau perusahaan swasta. $^{12}$

Pengaturan Otoritas Pelabuhan sebagai regulator dalam sektor pelabuhan sesuai dengan Pasal 1 angka 26 dan 27, Pasal 81 ayat (2) dan (3) Undang-Undang No. 17 Tahun 2008, serta Pasal 38 ayat (2) Peraturan Pemerintah No. 61 Tahun 2009. Berdasarkan pengaturan sebagaimana yang disebutkan, Otoritas Pelabuhan adalah lembaga pemerintah di Pelabuhan yang melaksanakan fungsi pengaturan, pengendalian dan pengawasan kegiatan kepelabuhanan yang diusahakan secara komersial.

Sedangkan untuk fungsi yang sama dalam sektor pelabuhan yang belum diusahakan secara komersial dilaksanakan oleh Unit Penyelenggaraan Pelabuhan. ${ }^{13}$

Pengaturan mengenai pemisahan pemegang fungsi regulator dan operator pada Undang-Undang Nomor 17 Tahun 2008 tentang Pelayaran menyebabkan PT. Pelabuhan Indonesia yang merupakan BUMN kehilangan hak monopolinya terhadap pelabuhan komersil yang ada di Indonesia.

\footnotetext{
${ }^{12}$ Barada Giyantana, Op.Cit, hlm.48

${ }^{13}$ Siti Anisah, (2014), Pengelolaan Pelabuhan dari Monopoli menuju Persaingan Usaha, Yogyakarta, Fakultas Hukum UII, hlm.48
}

Untuk lebih jelasnya, penghapusan hak monopoli pada pengusahaan pelabuhan dapat kita temukan pada Undang-Undang Nomor 17 Tahun 2008 tentang Pelayaran tepatnya pada beberapa Pasal. Pasal-Pasal tersebut antara lain adalah Pasal 1 angka 28, Pasal 1 angka 60, Pasal 91 ayat (1), Pasal 91 ayat (5), dan Pasal 92.

Konsekwensi dari hal tersebut pihak swasta seperti BUMD dan BUMN lainnya memiliki hak yang sama dengan PT. Pelabuhan Indonesia untuk melakukan pengusahaan pada pelabuhan dengan cara membentuk Badan Usaha Pelabuhan (BUP). Lebih lanjut PT. Pelabuhan Indonesia berubah status menjadi aktor atau murni pelaku usaha yang harus siap bersaing dengan pihak-pihak seperti BUMD dan pihak swasta lainnya.

Perbedaan Pendapat Antara PT. Pelabuhan Indonesia dengan Komisi Pengawas Persaingan Usaha tentang Kewenangan Monopoli PT.Pelabuhan Indonesia

Pasca lahirnya Undang-Undang Nomor 17 Tahun 2008 tentang Pelayaran, PT. Pelabuhan Indonesia kehilangan hak monopolinya. Permasalahan muncul ketika setelah lahirnya Undang-Undang Nomor 17 Tahun 2008 tidak diikuti dengan perubahan perilaku PT. Pelabuhan Indonesia dalam kegiatan usahanya. 
Meskipun Undang-Undang Nomor 17

Tahun 2008 tentang Pelayaran telah menghapus monopoli namun PT. Pelabuhan Indonesia masih saja melakukan kegiatan usaha seakan-akan hak monopolinya belum dihapus.

Perilaku PT. Pelabuhan Indonesia tersebut tentunya bertentangan dengan Undang-Undang Nomor 17 Tahun 2008 tentang Pelayaran dan Undang-Undang Nomor 5 Tahun 1999 tentang Larangan Praktek Monopoli dan Persaingan Usaha Tidak Sehat. PT. Pelabuhan Indonesia merasa apa yang dilakukannya bukanlah sebuah pelanggaran hukum. Disisi lain menurut Komisi Pengawas Persaingan Usaha memutus PT. Pelabuhan Indonesia telah melakukan pelanggaran terhadap Undang-Undang Nomor 5 Tahun 1999 tentang Larangan Praktek Monopoli dan Persaingan Usaha Tidak Sehat. Hal tersebut dapat kita lihat dari putusan Komisi Pengawas Persaingan Usaha pasca lahirnya Undang-Undang Nomor 17 Tahun 2008 tentang Pelayaran. Untuk memudahkan, penulis mencoba menyusun tabel analisis putusan Komisi Pengawas Persaingan Usaha sebagaimana berikut:

\begin{tabular}{|c|c|c|c|c|}
\hline No. & No. Putusan & $\begin{array}{c}\text { Bentuk } \\
\text { Pelanggaran }\end{array}$ & $\begin{array}{c}\text { Dugaan } \\
\text { Pelanggaran } \\
\text { Pasal }\end{array}$ & Putusan \\
\hline 1. & $\begin{array}{l}\text { No. 02/KPPU- } \\
\text { I/2013 tentang } \\
\text { Jasa Bongkar } \\
\text { Muat di } \\
\text { Pelabuhan } \\
\text { Teluk Bayur }\end{array}$ & $\begin{array}{l}\text { PT. Pelabuhan } \\
\text { Indonesia } \\
\text { selaku } \\
\text { pengelola } \\
\text { pelabuhan } \\
\text { menetapkan } \\
\text { persyaratan } \\
\text { dalam } \\
\text { perjanjian } \\
\text { penyewaan } \\
\text { lahan di } \\
\text { Pelabuhan } \\
\text { Teluk Bayur } \\
\text { dengan } \\
\text { mewajibkan } \\
\text { penyewa lahan } \\
\text { untuk } \\
\text { menggunakan } \\
\text { jasa bongkar } \\
\text { muat yang } \\
\text { dimiliki oleh } \\
\text { PT. Pelabuhan }\end{array}$ & $\begin{array}{l}\text { Pasal } 15 \text { ayat } \\
\text { (2) dan Pasal } \\
19 \text { huruf a dan } \\
\text { huruf } \\
\text { Undang- } \\
\text { Undang Nomor } \\
5 \text { Tahun } 1999\end{array}$ & $\begin{array}{l}\text { 1. PT. Pelabuhan Indonesia } \\
\text { terbukti secara sah dan } \\
\text { meyakinkan melanggar } \\
\text { Pasal } 15 \text { ayat (2) Undang- } \\
\text { undang Nomor 5 Tahun } \\
1999 \text { tentang Larangan } \\
\text { Praktek Monopoli dan } \\
\text { Persaingan Usaha Tidak } \\
\text { Sehat. } \\
\text { PT. Pelabuhan Indonesia } \\
\text { terbukti secara sah dan } \\
\text { meyakinkan melanggar } \\
\text { Pasal 19 huruf a dan b } \\
\text { Undang-undang Nomor 5 } \\
\text { Tahun 1999 tentang } \\
\text { Larangan Praktek } \\
\text { Monopoli dan Persaingan } \\
\text { Usaha Tidak Sehat. }\end{array}$ \\
\hline
\end{tabular}




\begin{tabular}{|c|c|c|c|c|}
\hline & & Indonesia & & \\
\hline 2. & $\begin{array}{l}\text { No. 12/KPPU- } \\
\text { I/2014 tentang } \\
\text { Kewajiban } \\
\text { Penggunaan } \\
\text { Gantry } \\
\text { Lufting Crane } \\
\text { untuk } \\
\text { Kegiatan } \\
\text { Bongkar Muat } \\
\text { di Pelabuhan } \\
\text { Tanjung Priok }\end{array}$ & $\begin{array}{l}\text { PT. Pelabuhan } \\
\text { Indonesia dan } \\
\text { anak } \\
\text { perusahaannya } \\
\text { yaitu PT. Multi } \\
\text { Terminal } \\
\text { Indonesia } \\
\text { selaku operator } \\
\text { terminal } \\
\text { mengeluarkan } \\
\text { surat } \\
\text { pemberitahuan } \\
\text { yang } \\
\text { mensyaratkan } \\
\text { bagi seluruh } \\
\text { pengguna jasa } \\
\text { pelabuhan } \\
\text { yang } \\
\text { menggunakan } \\
\text { jasa dermaga } \\
\text { untuk sandar } \\
\text { kapal di } \\
\text { Pelabuhan } \\
\text { Tanjung Priok } \\
\text { diwajibkan } \\
\text { menggunakan } \\
\text { Gantry Luffing } \\
\text { crane (GLC) } \\
\text { yang telah } \\
\text { disediakan } \\
\text { oleh PT. } \\
\text { Pelabuhan } \\
\text { Indonesia dan } \\
\text { anak } \\
\text { perusahaannya } \\
\text { PT. Multi } \\
\text { Terminal } \\
\text { Indonesia. }\end{array}$ & $\begin{array}{l}\text { Pasal } 17 \text { dan } \\
\text { Pasal } 15 \text { ayat } \\
\text { (2) Undang- } \\
\text { Undang Nomor } \\
5 \text { Tahun } 1999\end{array}$ & $\begin{array}{l}\text { 1. PT. Pelabuhan Indonesia } \\
\text { terbukti secara sah dan } \\
\text { meyakinkan melanggar } \\
\text { Pasal } 15 \text { ayat (2) Undang- } \\
\text { Undang Nomor } 5 \text { Tahun } \\
1999 \text { pada pasar } \\
\text { bersangkutan di dermaga } \\
\text { 101, 101 utara dan 102 } \\
\text { Pelabuhan Tanjung Priok } \\
\text { 2. Pelabuhan Indonesia II } \\
\text { terbukti secara sah dan } \\
\text { meyakinkan melanggar } \\
\text { Pasal 15 ayat (2) Undang- } \\
\text { Undang Nomor 5 Tahun } \\
\text { 1999 pada pasar } \\
\text { bersangkutan di dermaga } \\
\text { 114 dan 115 Pelabuhan } \\
\text { Tanjung Priok } \\
\text { PT. Pelabuhan Indonesia } \\
\text { tidak terbukti melanggar } \\
\text { Pasal 17 Undang-Undang } \\
\text { Nomor } 5 \text { Tahun 1999 }\end{array}$ \\
\hline
\end{tabular}

Tabel diatas memperlihatkan pertimbangan dan dasar mengapa Komisi Pengawas Persaingan Usaha berpendapat dan memutus PT. Pelabuhan Indonesia telah melakukan pelanggaran terhadap Undang-Undang Nomor 5 Tahun 1999. Kita bisa melihat pada kasus diatas yaitu kasus tentang jasa bongkar muat di pelabuhan Teluk Bayur. 
Pada kasus ini PT. Pelabuhan Indonesia selaku pengelola pelabuhan menetapkan persyaratan dalam perjanjian penyewaan lahan di Pelabuhan Teluk Bayur dengan mewajibkan penyewa lahan untuk menggunakan jasa bongkar muat yang dimiliki oleh PT. Pelabuhan Indonesia. Hal ini menyulitkan pelaku usaha lain yang menyebabkan pelaku

usaha lain kesulitan dalam melakukan kegiatan usahanya. PT. Pelabuhan Indonesia bukan lagi sebagai regulator

namun penentuan syarat-syarat oleh PT.Pelabuhan Indonesia terhadap kegiatan bongkar muat di pelabuha Teluk Bayur seakan-akan PT. Pelabuhan Indonesia masih sebagai regulator.

Hal yang sama terjadi pada kasus kewajiban penggunaan Gantry Lufting Crane untuk kegiatan bongkar muat di pelabuhan Tanjung Priok. PT. Pelabuhan Indonesia dan anak perusahaannya yaitu PT. Multi Terminal Indonesia selaku operator terminal mengeluarkan surat pemberitahuan yang mensyaratkan bagi seluruh pengguna jasa pelabuhan yang menggunakan jasa dermaga untuk sandar kapal di Pelabuhan Tanjung Priok diwajibkan menggunakan Gantry Luffing crane $(G L C)$ yang telah disediakan oleh
PT. Pelabuhan Indonesia dan anak perusahaannya PT. Multi Terminal Indonesia. Kembali perilaku PT. Pelabuhan Indonesia bertindak seakanakan masih menjadi regulator pada industry pelabuhan. Hal ini memperlihatkan adanya praktik monopoli yang dilakukan oleh PT. Pelabuhan Indonesia padahal PT. Pelabuhan Indonesia telah kehilangan hak monopolinya.

Meskipun demikian, pendapat Komisi Pengawas Persaingan Usaha yang menyatakan bahwa PT. Pelabuhan Indonesia telah melanggar UndangUndang Nomor 5 Tahun 1999 tentang Larangan Praktek Monopoli dan Persaingan Usaha bertolak belakang dengan pendapat PT. Pelabuhan Indonesia. Menurut PT. Pelabuhan Indonesia mereka tidak melakukan pelanggaran terhadap Undang-Undang Nomor 5 Tahun 1999. PT. Pelabuhan Indonesia menjadikan Surat Menteri

Perhubungan HK/003/1/11/phb/2011 sebagai dasar mereka melakukan kegiatan usaha di pelabuhan.

Surat Menteri Perhubungan Nomor HK/003/1/11/phb/2011 berisi tentang pelaksanaan Undang-Undang Nomor 17 Tahun 2008 tentang Pelayaran terhadap PT. Pelabuhan Indonesia, I,II, III, IV. Pada 
poin-poin penting yang merupakan sebagian isi dari Surat Menteri Perhubungan tersebut antara lain: ${ }^{14}$

1. pemberian pelayanan jasa kepelabuhanan oleh PT Pelindo dilakukan berdasarkan konsesi dari Otoritas Pelabuhan yang dituangkan dalam bentuk perjanjian. Sambil menunggu perjanjian konsesi maka pelayanan jasa kepelabuhanan termasuk pelayanan jasa labuh tetap dilakukan oleh PT Pelindo

2. konsesi pelayanan jasa kepelabuhanan pada terminal yang pada saat ditetapkannya UU Nomor 17 tahun 2008 telah diusahakan PT Pelindo diberikan PT Pelindo tanpa melalui mekanisme lelang.

3. Sebagai Badan Usaha Pelabuhan, PT Pelindo bertanggung jawab terhadap kinerja pelayanan di terminal yang diusahakan.

Atas dasar poin-poin teresebut PT. Pelabuhan Indonesia masih saja melakukan monopoli, padahal UndangUndang Nomor 17 Tahun 2008 tentang Pelayaran telah menghapus monopoli dalam sektor pelabuhan.

\footnotetext{
${ }^{14}$ Berita Surabaya, (2011), Pembagian Asset Pelindo Menunggu Perintah Kemhub, Tersedia pada http://beritasurabaya.net/index_sub.php?categ ory $=7 \& i d=2148$, [Akses pada senin, 14 Maret 2017].
}

Surat Menteri Perhubungan HK/003/1/11/phb/2011 yang dijadikan dasar oleh PT. Pelabuhan Indonesia sebagai tameng untuk melakukan monopoli tidaklah tepat karena bertentangan dengan Undang-Undang Nomor 17 Tahun 2008 tentang Pelayaran. Hal tersebut semakin diperkuat dengan keterangan ahli pada putusan Komisi Pengawas Persaingan Usaha No.02/KPPUI/2013 terkait kasus jasa bongkar muat di Pelabuhan Teluk Bayur yang menyatakan masih perlunya harmonisasi Peraturan Menteri Perhubungan dengan konsesi.

Pada butir 2 huruf b, c dan d Surat Menteri Perhubungan Perhubungan HK/003/1/11/phb/2011 disebutkan bahwa Otoritas Pelabuhan memberikan konsesi kepada PT. Pelabuhan Indonesia untuk melaksanakan pelayanan jasa kepelabuhanan di terminal-terminalnya. Konsesi tersebut diberikan tanpa melalui mekanisme lelang setelah selesai dilakukan audit aset dan evaluasi terhadap PT. Pelabuhan Indonesia secara menyeluruh. Selain itu dalam penjelasan surat tersebut juga dikatakan apabila belum adanya konsesi maka pelayanan jasa kepelabuhanan tetap dilakukan oleh PT. Pelabuhan Indonesia I,II, III, dan IV sambil menunggu adanya perjanjian konsesi. 
Butir 2 huruf e disebutkan bahwa apabila dilakukan pengembangan fasilitas pelabuhan yang berada diatas aset/lahan milik PT. Pelabuhan Indonesia juga harus mendapatkan konsesi dimana hal tersebut adalah bagian dari konsesi. Di sisi lain, dalam butir 2 huruf g disebutkan bahwa aset yang telah dimiliki oleh PT. Pelabuhan Indonesia adalah kekayaan negara yang dipisahkan dan tetap menjadi aset milik PT. Pelabuhan Indonesia. Berdasarkan hal ini PT. Pelabuhan Indonesia yang merupakan BUMN harus tetap mendapatkan konsesi dari pemerintah dalam mengelola aset/kekayaan milik negara.

Pada Pasal 92 Undang-Undang Nomor 17 Tahun 2008 tentang Pelayaran secara jelas telah dinyatakan bahwa kegiatan penyediaan dan/atau pelayanan jasa kepelabuhanan yang dilaksanakan oleh Badan Usaha Pelabuhan dilakukan berdasarkan konsesi atau bentuk lainnya dari Otoritas Pelabuhan. Dalam Pasal 82 ayat (4) Undang-Undang Nomor 17 Tahun 2008 tentang Pelayaran dikatakan bahwa Otoritas Pelabuhan merupakan wakil dari pemerintah yang dalam hal ini adalah menteri yang bertanggung jawab dalam bidang pelayaran.yang bertanggung jawab dalam bidang pelayaran. berdasarkan Pasal 12 Peraturan Presiden Nomor 40 Tahun
2015 bahwa yang bertanggung jawab dalam kasus atau bidang pelayaran adalah Kementerian Perhubungan khususnya Direktorat Jenderal Perhubungan Laut yang mempunyai tugas menyelenggarakan perumusan dan pelaksanaan kebijakan di bidang pelayaran.

Pemberian konsesi oleh pemerintah yang dalam hal ini adalah Direktorat Jenderal Perhubungan Laut yang diwakili oleh Otoritas Pelabuhan sebagaimana yang diatur dalam Undang-Undang Nomor 17 Tahun 2008 tentang Pelayaran sebenarnya sudah tepat apabila dalam hal ini pemerintah yang merupakan bagian dari negara posisinya sebagai regulator. Akan tetapi Surat Menteri Perhubungan HK/003/1/11/phb/2011 yang menyatakan bahwa aset yang dimiliki oleh PT. Pelabuhan Indonesia merupakan aset negara yang dipisahkan dan tetap menjadi aset PT. Pelabuhan Indonesia berarti PT. Pelabuhan Indonesia bertanggung jawab atas aset tersebut yang merupakan kekayaan milik negara. Secara tidak langsung PT. Pelabuhan Indonesia sebagai BUMN juga bertindak sebagai bagian dari negara adalah pelaku usaha. Hal ini memperlihatkan akibat dari adanya Surat Kementerian Perhubungan HK/003/1/11/phb/2011 menyebabkan pelaksanaan Undang-Undang Nomor 17 
Tahun 2008 yang memisahkan regulator dan operator tidak terlaksana dan terkesan memberikan hak monopoli bagi PT. Pelabuhan Indonesia.

Apabila kita telaah, Surat Menteri Perhubungan HK/003/1/11/phb/2011 tidak dapat dijadikan dasar oleh PT. Pelabuhan Indonesia untuk tetap melakukan monopoli pada sektor pelabuhan. Surat Menteri Perhubungan tersebut bertentangan dengan Undang-Undang Nomor 17 Tahun 2008. ${ }^{15}$ Menurut Adolf Merkl, norma hukum mempunyai dua wajah dimana suatu norma hukum ke atas bersumber dari norma hukum diatasnya dan ke bawah menjadi sumber dan dasar bagi norma hukum di bawahnya. ${ }^{16}$ Pada Stufen theory yang dikemukakan oleh Hans Kelsen, suatu norma yang lebih rendah berlaku, bersumber dan berdasar

\footnotetext{
${ }^{15}$ Lihat Pasal 7 dan 8 Undang-Undang Nomor 12 Tahun 2011 beserta penjelasan terkait hal tersebut. 2011 Surat Menteri bahkan tidak tercantum dalam hierarki perundang-undangan meskipun dalam penjelasan dikatakan ada bentuk peraturan lain yang diakui diluar dari hal yang diatur dalam Pasal 7 yang sifatnya mengikat. Walaupun demikian peraturan diluar dari peraturan yang masuk dalam hierarki perundang-undangan yang diatur dalam Pasal 7 tersebut tidak boleh bertentangan dengan Peraturan Perundang-undangan yang ada diatasnya. Dalam konteks tulisan ini Surat Keputusan Menteri Perhubungan bertentangan dengan Undang-Undang Nomor 17 Tahun 2008 tentang Pelayaran.

${ }^{16}$ Maria Farida Indriarti, (2005), Ilmu PerundangUndangan, Dasar-dasar pembentukannya, Yogyakarta: Kanisius, hlm 26.
}

pada norma yang lebih tinggi. ${ }^{17}$ Secara hierarki peraturan perundang-undangan berdasarkan Pasal 7 ayat (1) UndangUndang Nomor 12 Tahun 2011 posisi Undang-Undang Nomor 17 Tahun 2008 lebih tinggi dibandingkan surat menteri maka monopoli yang dilakukan PT. Pelabuhan Indonesia tidak dibenarkan. Pasal 7 dan 8 Undang-Undang Nomor 12 Tahun 2011 beserta penjelasan terkait hal tersebut. 2011 Surat Menteri bahkan tidak tercantum dalam hierarki perundangundangan meskipun dalam penjelasan dikatakan ada bentuk peraturan lain yang diakui diluar dari hal yang diatur dalam Pasal 7 yang sifatnya mengikat.

Monopoli PT. Pelabuhan dalam Perspektif Hukum Persaingan Usaha

\section{Eksistensi Undang-Undang Nomor}

5 Tahun 1999 tentang Larangan Praktek Monopoli dan Persaingan Usaha Tidak Sehat memiliki tujuan ekonomi demi terciptanya iklim usaha yang sehat, efektif, dan efisien. Undang- Undang Nomor 5 Tahun 1999. juga bertujuan untuk menciptakan keadilan ekonomi demi mendorong pertumbuhan ekonomi dan menjaga agar ekonomi pasar bekerja dengan wajar, serta untuk mencegah timbulnya pemusatan ekonomi pada

17 Maria Farida indrati (ed.5), (2007), Ilmu Perundang-Undangan, Jenis, Fungsi dan Materi Muatan, Kanisius, Yogyakarta, hlm 141 
pelaku usaha tertentu yang dapat menghalangi persaingan yang sehat dan wajar. ${ }^{18}$ Oleh karena itu dengan adanya Undang-Undang Nomor 5 Tahun 1999 dapat memberikan jaminan kepastian hukum dan perlindungan yang sama kepada setiap pelaku usaha dalam berusaha dengan cara mencegah timbulnya praktik-praktik monopoli dan/atau persaingan usaha yang tidak sehat. ${ }^{19}$ Disamping itu adanya Undang-Undang Nomor 5 Tahun 1999 juga sebagai tool of social control and a tool of social engineering guna peningkatan efisiensi ekonomi nasional. ${ }^{20}$

Apabila mengacu pada UndangUndang Nomor 5 Tahun 1999 tentang Larangan Praktek Monopoli dan Persaingan Usaha Tidak Sehat sesungguhnya monopoli tidak dilarang. Menjadi dilarang ketika terjadi penyalahgunaan posisi monopoli. ${ }^{21}$ Oleh karena itu Undang-Undang Nomor 5 Tahun 1999 membedakan antara monopoli

18 Syamsul Maarif, (2010), Merger Dalam Perspektif Hukum Persaingan Usaha, Jakarta : Degraf Publising, hlm. 1.

19 Rachmadi Usman, (2013), Hukum Persaingan Usaha di Indonesia, Jakarta: Sinar Grafika, hlm.13.

20 Devi Meyliana, (2013), Hukum Persaingan Usaha "Studi Konsep Pembuktian Terhadap Perjanjian Penetapan Harga dalam Persaingan Usaha”, Malang: Setara Press, hlm. 13.

${ }^{21}$ Rahadi Wasi Bintoro, (2010), Aspek Hukum Zonasi Pasar Tradisional dan Pasar Modern", Jurnal Dinamika Hukum vol.10 No.3, Fakultas Hukum Universitas Jenderal Soedirman, Purwokerto, hlm.364. dan praktek monopoli. Mengenai larangan terkait dengan kegiatan yang dapat menyebabkan terjadinya praktek monopoli telah diatur dalam Pasal 17 UndangUndang Nomor 5 Tahun 1999. Adapun unsur-unsur yang terdapat dalam Pasal 17 tersebut antara lain sebagai berikut: ${ }^{22}$

a. Melakukan perbuatan penguasaan atas suatu produk

b. Melakukan perbuatan atas pemasaran suatu produk

c. Penguasaan tersebut dapat mengakibatkan terjadinya praktek monopoli

d. Penguasaan tersebut dapat mengakibatkan terjadinya praktek persaingan usaha tidak sehat

$$
\text { Selanjutnya Pasal } 50 \text { dan } 51
$$
Undang-Undang Nomor 5 Tahun 1999 tentang Larangan Praktek Monopoli dan Persaingan Usaha Tidak Sehat juga mengatur tentang monopoli yang diperbolehkan. Dalam Pasal 50 disebutkan bahwa salah satu monopoli yang diperbolehkan adalah untuk melaksanakan Undang-Undang. Sedangkan dalam Pasal 51 monopoli diperbolehkan apabila berkaitan dengan produksi atau pemasaran barang dan atau jasa yang berkaitan

\footnotetext{
${ }^{22}$ Galuh Puspaningrum, (2013), Hukum Persaingan Usaha (Perjanjian dan Kegiatan yang Dilarang dalam Hukum Persaingan Usaha di Indonesia, Yogyakarta: Aswaja Pressindo, hlm.103.
} 
dengan hajat hidup orang banyak serta cabang-cabang yang penting bagi negara. Monopoli itu sendiri juga harus dilaksanakan oleh pemerintah melalui Badan Usaha Milik Negara atau lembanga yang dibentuk atau ditunjuk oleh pemerintah.

PT. Pelabuhan Indonesia adalah Badan Usaha Milik Negara yang mengelola pelabuhan berdasarkan 4 Peraturan Pemerintah. Peraturan Pemerintah tersebut antara lain Peraturan Pemerintah Nomor 56-59 Tahun 1991 Tentang Pengalihan Bentuk Perusahaan Umum (Perum) Pelabuhan I-IV menjadi Perusahaan Perseroan (Persero). Dari Peraturan Pemerintah tersebut tercantum maksud dan tujuan Perusahaan Perseroan dibentuk serta modalnya. ${ }^{23}$

Timbul pertanyaan, apakah dengan lahirnya Undang-Undang Nomor 17 Tahun 2008 tentang Pelayaran perbuatan yang dilakukan PT. Pelabuhan Indonesia masih masuk dalam kategori monopoli yang dikecualikan sebagaimana diatur dalam Pasal 50 huruf a Undang-Undang Nomor 5 Tahun 1999 tentang Larangan Praktek Monopoli dan Persaingan Usaha Tidak Sehat.

\footnotetext{
${ }^{23}$ Pelindo, (2013), Holding Pelindo Tidak Menyalahi Aturan, https://www.pelindo.co.id/medi a/berita-terkini/q/holding-pelindo-tidak-menyalahiaturan, [Akses 3 Agustus 2017].
}

Apabila kita merujuk pada Pasal 344 Undang-Undang Nomor 17 Tahun 2008 tentang Pelayaran memang benar dikatakan bahwa pada saat pemberlakuan Undang-Undang Nomor 17 Tahun 2008 baik Pemerintah, Pemerintah daerah, dan Badan Usaha Milik Negara yang sebelumnya menyelenggarakan kegiatan pengusahaan pelabuhan tetap melaksanakan kegiatan tersebut. Akan tetapi pada poin selanjutnya perlu diperhatikan bahwa penyelenggaraan tersebut diberi batas waktu. Dikatakan dalam poin selanjutnya bahwa dalam waktu paling lama 3 tahun sejak UndangUndang Pelayaran yang baru berlaku, kegiatan usaha yang dilakukan oleh Pemerintah, Pemerintah Daerah, dan Badan Usaha Milik Negara wajib untuk dilakukan penyesuaian sebagaimana pengaturan dalam Undang-Undang Pelayaran yang baru.

Pasal 344 pada poin lain dikatakan bahwa kegiatan pengusahaan pelabuhan oleh Badan Usaha Milik Negara tetap diselenggarakan oleh Badan Usaha Milik Negara. Pada penjelasan Pasal 344 ayat (2) dan (3) dikatakan bahwa yang dimaksud dengan tetap diselenggarakan oleh Badan Usaha Milik Negara adalah Badan Usaha Milik Negara yang didirikan berdasarkan Peraturan Pemerintah Nomor 56 Tahun 
1991, Peraturan Pemerintah Nomor 57 Tahun 1991, Peraturan Pemerintah Nomor 58 Tahun 1991, dan Peraturan Pemerintah Nomor 59 Tahun 1991. Pada intinya Pasal 344 Undang-Undang Nomor 17 Tahun 2008 tentang Pelayaran secara jelas telah mempertegas siapa BUMN yang dimaksud dalam Undang-Undang tersebut yang dapat menjalankan kegiatan usaha di pelabuhan sebagaimana diatur dalam Pasal 90 Undang-Undang Nomor 17 Tahun 2017. Lebih lanjut telah diuraikan adanya pemisahan fungsi regulator dan operator di pelabuhan semenjak lahirnya UndangUndang Nomor 17 Tahun 2008 tentang pelayaran menyebabkan status PT. Pelabuhan Indonesia yang berupa Badan Usaha Pelabuhan menjadi sebagai operator yang mengoperasikan terminal dan fasilitas lainnya. $^{24}$

Meskipun demikian dalam Undang-Undang Nomor 17 Tahun 2008 tentang Pelayaran tidak menyatakan bahwa PT. Pelabuhan Indonesia merupakan satusatunya operator dalam sektor pelabuhan. Hal tersebut sebagaimana dinyatakan dalam Pasal 1 angka 60 Undang-Undang Nomor 17 Tahun 2008 tentang Pelayaran

Berdasarkan hal-hal yang telah ditentukan oleh Undang-Undang Nomor

\footnotetext{
${ }^{24}$ Lihat Pasal 92 Undang-Undang Nomor 17 Tahun 2008 tentang Pelayaran.
}

17 Tahun 2008 sebagai Undang-Undang Pelayaran yang baru jelas PT. Pelabuhan Indonesia tidak lagi bertindak sebagai operator tunggal dalam sektor pelabuhan. Jelas kita lihat bahwa Undang-Undang Nomor 17 Tahun 2008 memberikan kesempatan bagi entitas bisnis lain selain PT. Pelabuhan Indonesia untuk dapat bertindak sebagai operator pelabuhan dan/atau operator terminal selama memperoleh konsesi dari otoritas pelabuhan. ${ }^{25}$ Oleh karena itu, apabila PT. Pelabuhan Indonesia masih bertindak seolah-olah sebagai operator tunggal yang masih memiliki hak monopoli maka hal tersebut sesungguhnya tidak sesuai dengan tujuan dan inti dari alasan pemberlakuan Undang-Undang Nomor 17 Tahun 2008.

Sebelumnya telah diuraikan bahwa Surat Menteri Perhubungan Nomor 003/1/11/phb/2011 bertentangan dengan Undang-Undang Nomor 17 Tahun 2008 tentang Pelayaran. Surat Menteri Perhubungan tersebut menyebabkan pemisahan antara regulator dan operator di pelabuhan tidak terlaksana. Hal ini menyebabkan PT. Pelabuhan Indonesia menjadikan surat tersebut sebagai dasar dalam melakukan kegiatan usahanya sehingga terjadi monopoli. Oleh karena itu selain bertentangan dengan Undang-

${ }^{25}$ Siti Anisah, Op.Cit., hlm.78 
Undang Nomor 17 Tahun 2008 Surat

Menteri Perhubungan tersebut juga bertentangan dengan Undang-Undang Nomor 5 Tahun 1999 tentang Larangan Praktek Monopoli dan Persaingan Usaha Tidak Sehat.

Monopoli dapat terjadi melalui dua cara:

1. Monopoli alamiah (natural monopoly), dimana monopoli ini terjadi akibat kemampuan seseorang atau sekelompok pelaku usaha yang mempunyai satu kelebihan tertentu sehingga membuat pelaku usaha lain kalah bersaing. ${ }^{26}$

2. Monopoli berdasarkan hukum (monopoly by law), yakni monopoli yang berasal dari pemberian negara seperti yang termaktub dalam Pasal 33 Undang-Undang Dasar 1945 yang selanjutnya dilindungi oleh UndangUndang dan Peraturan di bawahnya. Misalnya, pada perusahaan listrik negara, Pertamina dan sebagainya. ${ }^{27}$

Pasal 50 huruf a menyatakan bahwa salah satu bentuk monopoli yang dikecualikan adalah monopoli yang dilakukan untuk melaksanakan perintah peraturan perundang-undangan yang berlaku. Inilah yang termasuk dalam monopoly by law. Berdasarkan Pertaruran

\footnotetext{
${ }^{26}$ Mustafa Kamal Rokan (ed.2), (2012), Hukum Persaingan Usaha Teori dan Praktiknya di Indonesia, Jakarta: PT. Raja Grafindo Persada, hlm.16.

${ }^{27}$ Ibid.
}

Komisi Pengawas Persaingan Usaha Nomor 05 Tahun 2009 tentang Pedoman Pelaksanaan Pasal 50 huruf a UndangUndang Nomor 5 Tahun 1999 dinyatakan apabila terdapat peraturan perundangundangan yang tidak secara langsung diamanatkan sebagai peraturan pelaksana dari suatu Undang-Undang, maka peraturan tersebut tidak dapat mengenyampingkan Undang-Undang Nomor 5 Tahun 1999.

Dengan demikian apabila materi peraturan perundang-undangan di bawah undang-undang tersebut bertentangan dengan Undang-Undang Nomor 5 Tahun 1999 maka tidak dapat diterjemahkan sebagai pengecualian sebagaimana diatur dalam Pasal 50 huruf a Undang-Undang Nomor 5 Tahun 1999. Monopoli yang dilakukan atas perintah undang-undang diperbolehkan, akan tetapi apabila monopoli yang dilakukan tersebut menyebabkan terjadinya praktek monopoli dan atau persaingan usaha yang tidak sehat, maka monopoli tersebut tetap dilarang berdasarkan Undang-Undang Nomor 5 Tahun $1999 .^{28}$

\section{Penutup}

28 Syamsul Ma'arif, (2010), Modul Hukum Antimonopoli \& Persaingan Usaha Tidak Sehat, Yogyakarta: Fakultas Hukum Universitas Islam Indonesia, hlm.17. 
Kegiatan usaha yang dilakukan oleh PT. Pelabuhan Indonesia tidak termasuk dalam pengecualian yang diatur dalam Pasal 50 huruf a Undang-Undang Nomor 5 Tahun 1999 tentang Larangan Praktik Monopoli dan Persaingan Usaha Tidak Sehat. Hal-hal yang menjadi alasan mengapa Kegiatan usaha yang dilakukan oleh PT. Pelabuhan Indonesia tidak termasuk dalam pengecualian yang diatur dalam Pasal 50 a Undang-Undang Nomor 5 Tahun 1999 antara lain karena surat menteri yang dijadikan dasar hukum PT. Pelabuhan Indonesia melakukan monopoli pada pengelolaan pelabuhan bertentangan dengan Undang-Undang Nomor 17 Tahun 2008 tentang Pelayaran. Undang-Undang Nomor 17 Tahun 2008 tentang Pelayaran telah menghapus adanya monopoli dalam pengelolaan pelabuhan sebagaimana dinyatakan dalam Pasal 1 angka 28, Pasal 1 angka 60, Pasal 91 ayat (1), Pasal 91 ayat (5) dan Pasal 92 Undang-Undang Nomor 17 Tahun 2008 tentang Pelayaran. Selain itu kegiatan usaha pengelolaan pelabuhan seperti bongkar muat dan halhal terkait kegiatan bongkar muat yang dilakukan oleh PT. Pelabuhan Indonesia menyebabkan terjadinya praktek monopoli dan persaingan usaha yang tidak sehat sebagaimana yang dapat dilihat berdasarkan putusan-putusan KPPU yang melibatkan PT. Pelabuhan Indonesia sebagai pihak terlapor.

PT. Pelindo harus menyadari bahwa sebagai konsekuensi lahirnya Undang-Undang Nomor 17 Tahun 2008 telah merubah status PT.Pelindo sebagai pelaku usaha murni dan bukan satusatunya operator yang berhak atas pengusahaan dan pengelolaan sektor kepelabuhanan. Tujuannya adalah perubahan struktur industri kepelabuhanan di Indonesia yang awalnya bersifat monopoly industries dapat berubah menjadi competition industries dapat tercapai. Selain itu perlu adanya penyesuain antar peraturan khususnya peraturan dibawah Undang-Undang Nomor 17 Tahun 2008 tentang Pelayaran. Hal ini bertujuan agar tidak terjadi tumpang tindih antar peraturan yang menyebabkan masalah dalam pengelolaan industry pelabuhan. Pada akhirnya antar pelaku usaha akan berkompetisi secara sehat tanpa melanggar Undang -Undang Nomor 5 Tahun 1999 tentang Larangan Praktik Monopoli dan Persaingan Usaha Tidak Sehat. 


\section{E. Daftar Pustaka}

Buku

D.A. Lasse, (2014), Manajemen Kepelabuhanan, Jakarta: Rajawali Pers

Devi Meyliana, (2013), Hukum Persaingan Usaha "Studi Konsep Pembuktian Terhadap Perjanjian Penetapan Harga dalam Persaingan Usaha”, Malang: Setara Press

Fahri Hamzah, (2012), Negara BUMN dan

Kesejahteraan Rakyat, Jakarta:

Yayasan Faham Indonesia.gal

Galuh Puspaningrum, (2013), Hukum

Persaingan Usaha (Perjanjian dan Kegiatan yang Dilarang dalam Hukum Persaingan Usaha di Indonesia, Yogyakarta: Aswaja Pressindo.

Herman Budi Sasono, (2012), Manajemen Pelabuhan \& Realisasi Ekspor Impor, Yogyakarta: Penerbit ANDI.

Maria Farida indrati (ed.5), (2007), Ilmu

Perundang-Undangan, Jenis,

Fungsi dan Materi Muatan,

Kanisius, Yogyakarta.

, Ilmu Perundang-Undangan,

Dasar-dasar pembentukannya,

Cetakan kelima, Kanisius, Yogyakarta, 2005
Mustafa Kamal Rokan (ed.2), (2012), Hukum Persaingan Usaha Teori dan Praktiknya di Indonesia, Jakarta: PT. Raja Grafindo Persada

Rachmadi Usman, (2013), Hukum Persaingan Usaha di Indonesia, Jakarta: Sinar Grafika

Siti Anisah, (2014), Pengelolaan Pelabuhan dari Monopoli menuju Persaingan Usaha, Yogyakarta, Fakultas Hukum UII.

Syamsul Maarif, (2010), Merger Dalam Perspektif Hukum Persaingan Usaha, Jakarta : Degraf Publising.

Syamsul Ma'arif, Modul Hukum Antimonopoli \& Persaingan Usaha Tidak Sehat, Magister Ilmu Hukum Universitas Islam Indonesia, 2010

Jurnal

Barada Giyantana, Implementasi Kebijakan Restrukturisasi Pengelolaan Pelabuhan (Studi Kasus di PT. (Persero) Pelabuhan Indonesia III Cabang Tanjung Perak Surabaya, Journal Universitas Airlangga Kebijakan dan Manajemen 
Publik, Volume 1, Nomor 1, 2013

Hamud Balfas, Kajian Privatisasi Pelabuhan Berdasarkan

Undang-Undang Nomor 17

Tahun 2008 tentang Pelayaran, Jurnal Hukum PRIORIS, Vol. 4 No.3, 2015

Rahadi Wasi Bintoro, Aspek Hukum Zonasi Pasar Tradisional dan Pasar Modern", Jurnal Dinamika Hukum vol.10 No.3, Fakultas Hukum Universitas Jenderal Soedirman, 2010

Undang-Undang:

Undang-Undang Dasar Negara Republik Indonesia Tahun 1945

Undang-Undang Nomor 21 Tahun 1992 tentang Pelayaran

Undang-Undang Nomor 17 Tahun 2008 tentang Pelayaran

Undang-Undang Nomor 5 Tahun 1999 tentang Larangan Praktek Monopoli dan Persaingan Usaha Tidak Sehat

Undang-Undang Nomor 12 Tahun 2011 tentang Pembentukan Peraturan Perundang-Undangan

Surat Menteri Perhubungan Nomor HK 003/1/11Phb2011
Online:



Gatra.com, (2016), Pelindo II: Monopoli Sah Menurut UndangUndang, Tersedia pada http:// www.gatra.com/ekonomi1/28991-pelindo-ii-monopolisah-menurut-undangundang.html, [Akses pada tanggal 2 Agustus 2017].

Pelindo, (2013), Holding Pelindo Tidak Menyalahi Aturan, https://www .pelindo.co.id/media/beritaterkini/q/holding-pelindo-tidakmenyalahi-aturan, [Akses 3 Agustus 2017].

Berita Surabaya, (2011), Pembagian Asset Pelindo Menunggu Perintah Kemhub, Tersedia pada http://beritasurabaya.net/index_sub.p

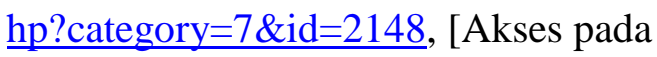
senin, 14 Maret 2017]. 